資 料

\title{
因果関係モデルによる高校生の進路意識の分析
}

\author{
鈴 木 規 夫 ${ }^{1}$ 柳 井 晴 夫 ${ }^{1}$
}

\section{AN ANALYSIS OF STRUCTURAL RELATIONSHIP BETWEEN FACTORS INFLUENCING CAREER CHOICE OF HIGH SCHOOL STUDENTS BY USING A CAUSAL MODEL}

\author{
Norio Suzuki AND Haruo YanaI
}

\begin{abstract}
In spite of the fact that career guidance in high schools has recently emphasized students' academic achievement, it is desirable that high school students develop career planning for future selection of their majors at the university and/or jobs, by considering not only academic achievement but also interests and attitudes. The primary purpose of this research was to investigate how high school students react facing their choice in future careers. For such purpose, we specified a causal model in which some relationships were assumed between eight constructs of career planning taking into account both aptitude and achievement. The model was subjected to covariance structure analysis, using data collected from 12,788 students in 84 high schools throughout Japan. It was shown that the appropriateness of the FIT Index was considerably high while some path coefficients were statistically significant, thus establishing the validity of the assumed model. From the analysis, it was found that guidance emphasizing academic achievement was not independent of the guidance emphasizing scholastic aptitude.
\end{abstract}

Key words : career planning, scholastic aptitude, academic achievement, causal model, covariance structure analysis.

\section{問 題}

高校生が将来の進路を選択するにあたって，自己を 理解し, 自己の生き方を考えながら進学先や職業につ いての展望をもつことは重要である。進路の選択先と して大学の学部を考えたとき，そこで考慮すべき特性 としては，単に学力だけではなく，社会や人間に対す る興味・関心，あるいは価值観や性格といった人格的 特性に関わる要因がある。柳井 (1973) は，この人格的 特性が学部で異なる特徵をもつていることを示してお り，また，浜田 (1991) が実施した全国の大学教師を対 象とした調査では，専門分野に必要な資質として教科

1 大学入試センター研究開発部 (Research Division, The National Center For University Entrance Examination)
の成績，価値観，関心の方向，興味，ものの見方・考 え方を取り上げ，それらの資質が専門分野によってそ れぞれ異なった方向を示していることを報告し，専門 分野の選択には学力以外の要因も重要であることを示 している。このように, 進学先の特徵が単に学力だけ に規定されていないのであれば，生徒自身が学力以外 の興味・関心といった人格的特性を重視した進路意識 をもつことは，大学入学後の専門課程の教育を成功さ せるためにも重要な要因となってくる。

ところで，今の生徒の考えている進路意識はどのよ うなものであろうか。現在の大学入試が学力的側面を 重視した形で行われている限り，下山 (1984) が指摘し ているように，進路を決める場合，日本の社会では学 力成績が最も重要な要因となってくることは否めない。 
しかし，柳井ら（1989）による全国の約1600校の生徒 (2 年生）約 10 万人を対象にした生徒の進路意識について の調查結果によれば，進学を決める場合，約 7 割の生 徒が専門分野を決めてから大学を決めると回答してお り，大学を決めてから専門分野を決めると回答した生 徒は 1 割強にすぎないとの報告がある。各専門分野で 要求される資質が価值観や関心の方向などと密接に関 わりがあることを考慮すれば，この回答結果から「生 徒の進路意識の中には, 自分の興味・関心といった人 格的特性を生かすことのできる専門分野を目指しなが ら学力とのバランスを考慮し, 最適の進路を決定しよ う」としている姿が同える。しかし，多くの学校で学 力中心の進路指導が行われている状況を考えると, 生 徒の意識の中には学力的側面の重視と人格的特性の考 慮が必ずしもバランスがとれた形で存在しているとは 限らず, 学力重視に陥り, 人格的特性を無視した進路 決定をしたため入学後に不適応現象を生じたといった 例は少なくない。そこで, 全国的規模により収集した 情報によって, この学力と人格的特性が進路指導の場 面や将来の展望においてどのような形で生徒の意識の 中に構造化されているかを実証的に検討することは, 現在の学力中心の進路指導の改善の上で有益な知見を 提供することになると思われる。Super（1953）によれ ば，職業的発達理論の中で適性の概念として，大きく 能力面と興味・関心あるいは価値観として捉えられる 人格的側面の 2 つの下位概念を示している。ここでは, 能力面を「学力 (観)」, 人格的側面を狭義の「適性(観)」 と定義して, 進路意識の形成を両面から捉えることに する。

本研究では, まず, 全国の高校の生徒を対象にした 進路選択に関する意識調査（柳井ら（1989））の項目のう ち, 特に進路意識を構成する上で重要と思われる項目 を取り上げ，それらの項目から探索的にいくつかの概 念を構成する。そして，この構成された概念を用いて 因果関係モデルを構築し, 共分散構造分析 (Joreskog \& Sorbom, 1984, 豊田, 1992）によって各概念間の関連を調べ る。豊田ら (1991) は, 教師を対象にした進路指導の実 態調査結果を利用して，同様の因果関係モデルによる 分析を試みている。そこでは偏差値中心の受験産業依 存型進路指導モデルおよびパーソナリティ面での適性 を考慮した進路指導モデルとそれぞれ 2 つのモデルを 提案している。2つのモデルを独立して構築した根拠 として, 各モデルの構成概念間の相関が低いことを上 げているが, このことは, 進路指導の教師の意識の中 には学力中心の進路指導の実態と適性重視の進路指導
の必要性を認識する理念とが分離した形で捉えられて いることを意味しているものと思われる。

しかし, 生徒の場合, 学力と適性を独立して進路意 識を考えることは難しい。実際，先に述べたように生 徒の進路選択は興味・関心などによって専門分野を選 択し, 次いで学力を考慮して大学を選択する傾向が強 いのであれば，両者が共に関わり合いながら進路意識 が形成されていくと考える方が自然であろう。本研究 では,この考え方を因果関係モデルに組み込むため, まず「適性重視の進路展望」と「学力重視の進路展望」 という 2 つ基本概念を構成した。そして，これらの 構成概念間の相関関係を考慮しながら進路指導上での 援助や不安, 努力などの進路意識を構成すると思われ る概念間との関係を示した因果関係モデルを構築した。 本研究の第 1 の目的は, モデルを設定した後, モデル の妥当性を調べ，モデルの検討を通して生徒の進路意 識の構造を明らかにすることである。モデルの設定に 関しては, 試行錯誤的にいくつかのモデルを構築し, 解釈の妥当性および AIC (Akaike's Information Criterion）によってモデル選択を行う。

本研究の第 2 の目的は, さらに性差や学年差あるい は進学率の違いが, 生徒の進路意識の形成にどのよう な影響を与えるかについて分析することである。この ため, それぞれについて同一の因果関係モデルを構築 し, 共分散構造分析抢よび分散分析などによって各モ デル間の比較を行う。

\section{方 法}

調査対象 本稿で取り扱うデー夕は, 大学入試セン ター研究開発部が平成元年度に共同研究プロジェクト の一環として実施した「高等学校の進学指導における 適性尊重に関する調査」(1991)によって収集されたもの である。調査は， 2 段抽出法による郵送方式，すなわ ち, 全国47都道府県から高校を各 2 校を抽出, (東京は 4 校, 名古屋, 大阪は 3 校), 次いで各高校において, 1 年生 および 2 年生とも各 2 クラスを教師により選出しても らうという手順で実施された。高校は, 100 人以上大学 入試センター試験志願者を出している高校を 1 校, 40～99人を出している高校から 1 校をそれぞれ無作為 に抽出した。

調査時期 調査票の発送：平成 2 年 2 月 調査票の 回収：平成 2 年 3 月 4 月

回収率 全98校中96校回収されたが(回収率 $98 \%$ )，分 析ではそのうち84校分（公立 74 校, 私立 10 校／男子校 7 校, 女子校 3 校, 共学 74 校 /北海道・東北 12 校, 関東 - 甲信越 17 校, 
東海・北陸 14 校, 近畿 9 校, 中・四国 16 校, 九州 14 校）にあた る 12,788 人のデー夕を用いる。(男子： 7,500 人 女子： 5,288 人, 1 年生 6,182 人 2 年生 : 6,606 人)

調査項目 全部で約120の調査項目のうち, 25項目を 本分析のために用いた。各項目とも 4 段階の評定尺度 による回答を求めた。分析に用いた項目としては,「適 性理解に必要と思われる項目」「進路指導で重視してほ しい項目」「進路決定の際に重視する事柄」「進路を考 える上での悩み」に関するものである。

因果関係モデルの構築 仮説として生徒について次 のような進路意識構造を考える。「生徒は将来の進路に 対してそれぞれ展望を抱いている。それは, 主として 個々の興味・関心など適性にもとづく場合もあり, 学 力中心の場合もある。しかし，両者はそれぞれが独立 に存在するのではなく相互に関連し合っている。その 中で, 典型的な意識構造として 2 つの場合を考えてみ る。1つは, 興味・関心など適性を重視した進路展望 をもった場合である。この場合, 生徒は自己を知るこ とに努め, 学力よりはむしろ自己の興味・関心などに 合った進路探索を行うことができるよう援助を求める。 また, そのような生徒は, 将来の職業や進学先につい ての不安も少なく, 実現可能性に向かっての努力もし ている。一方, 学力を重視した進路展望をもつ場合, 生徒は自己の理解に対しては他者からの援助を求める が, 進路指導では学力中心の指導を望む。ただし, 進 路指導で学力中心の指導を望む場合に限り，そのよう な生徒は学力不足による悩みも少なく, 進路の実現可 能性に向かっての努力をしているが, 単に学力重視の 進路展望をもつだけでは, 学力不足に悩み, また進路 の実現可能性に向かっての努力もしていない。」

上の仮説を検証するため, 調査結果から得られた項 白を利用して概念を構成する。分析では，25項目に関 する相関係数行列を用いて探索的因子分析を行う。こ こでは, 主因子法によって 5 因子を抽出し, 各因子間 の関係を把握するためプロマックス斜交回転を行い因 子間相関を求めた。次に因子間相関行列を見ながら， 相関の高い因子間 (0.2 以上) で因果関係が構築できるか を検討した。さらに項目の内容を吟味しながら解釈し やすいように作成した構成概念を TABLE 1 に示す。こ こでは，8つの概念を構成した。各構成概念は, 因子 のそれぞれを代表する項目からなり, 他の因子を代表 する項目は含まれていない。ただし，5因子から８つ の構成概念を作り上げたため，いくつかの概念は同一 の因子を代表する項目の一部を利用して表わしている。 例えば,「進路指導で重視してほしい項目」と「進路決
定の際に重視する事柄」に関連するいくつかの項目が 1 因子を代表する項目（因子負荷量が高い項目）として混 在していたが, 因果関係モデルでは「進路に対する展 望があるから,その展望に即した進路指導を期待する」 といった因果の方向性が重要な要素となるため, それ ぞれ別の構成概念として取り扱った。仮説の検証のた めに構築した因果関係モデルをパス・ダイアグラムに よって表現したものを FIG.1に示す。一般に,この種の パス・ダイアグラムの中には各観測変数や潜在変数に 関連した誤差変数を記号で表示することが多いが, 本 図では煩雑さを避けるため省略している。

モデルは,まず基本となる構成概念,「適性重視の進

TABLE 1 分析で用いられた項目によって構成された 概念

F X 1 <適性重視の進路展望>

$X_{1}$ 興味・関心・意欲を重視した進路決定を行う

$\mathrm{X}_{2}$ 将来の生き方に合った進路決定を行う

$\mathrm{X}_{3}$ 将来つきたい職業に関連した進路決定を行う

$\mathrm{X}_{4}$ 自分の性格に合った進路決定を行う

F X 2 <学力重視の進路展望〉

$\mathrm{X}_{5}$ 自分の学力に合った進路決定を行う

$\mathrm{X}_{6}$ 自分の得意科目を生かした進路決定を行う

F H 1 <適性理解のための援助〉

$\mathrm{X}_{7}$ 学校の先生の考えは進路適性を理解する上で役立つ

$\mathrm{X}_{8}$ 家族の助言は進路適性を理解する上で役立つ

$\mathrm{X}_{9}$ 友人や先輩の助言は進路適性を理解する上で役立つ

$\mathrm{X}_{10}$ 塾や予備校の助言は進路適性を理解する上で役立つ

F H 2 〈適性重視の進路指導〉

$\mathrm{X}_{11}$ 性格面を重視した進路指導をしてもらいたい

$\mathrm{X}_{12}$ 興味・関心・意欲を重視した進路指導をしてもらいたい

$\mathrm{X}_{13}$ 将来の生き方を重視した進路指導をしてもらいたい

$\mathrm{X}_{14}$ 身体的な特徵を重視した進路指導をしてもらいたい

FH 3 <学力重視の進路指導>

$\mathrm{X}_{15}$ 学業成績を重視した進路指導をしてもらいたい

$X_{16}$ 得意科日を重視した進路指導をしてもらいたい

$\mathrm{X}_{17}$ 偏差値中心の進路指導は必要である

FH 4 〈進路不明による悩み〉

$\mathrm{X}_{18}$ 自分の適性が分からない

$X_{19}$ 自分のつきたい職業が分からない

$\mathrm{X}_{20}$ 自分の進みたい専門分野が分からない

FH 5 〈学力不足による悩み>

$\mathrm{X}_{21}$ 学内成績の順位が低い

$\mathrm{X}_{22}$ 希望進路を達成するには不十分な成績である

$\mathrm{X}_{23}$ 自分の学力が不足している

F H 6 <実現可能性と努力〉

$\mathrm{X}_{24}$ 希望する進路の実現可能性が高い

$\mathrm{X}_{25}$ 希望する進路に向かって十分な努力をしている 


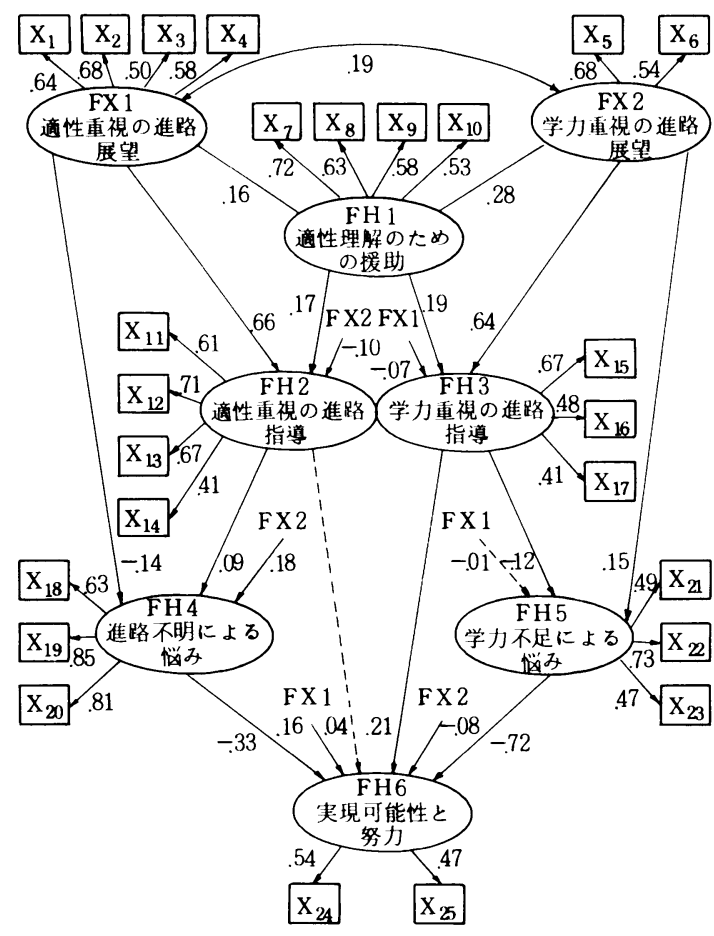

FIG. 1 生徒の進路意識に関するパス・ダイアグラム

路展望」と「学力重視の進路展望」を外生的潜在变数 として考え，両者は独立に存在するのではなく相互に 関連しているという仮説のもとに，双方向性をもたせ た。次に「適性重視の進路展望」をもつ生徒も，「学力 重視の進路展望」をもつ生徒も，いずれも「適性理解 のための援助」「適性重視の進路指導」「学力重視の進 路展望」を望み,「進路不明による悩み」や「学力不足 による悩み」を抱き，また「実現可能性と努力」を行っ ていると仮定し単方向の矢印を付した。さらに，各内 生的潜在変数間にもいくつかの因果関係を設定した。 「適性理解のための援助」を必要とする生徒は「適性重 視の進路指導」や「学力重視の進路指導」を望むと仮 定して単方向の矢印を付し，「適性重視の進路指導」を 望む生徒は「進路不明による悩み」や「学力不足によ る悩み」も少なく「実現可能性と努力」を行っている と仮定して単方向の矢印を付した。また，「進路不明に よる悩み」や「学力不足による悩み」を抱いている生 徒は「実現可能性と努力」を行っているとして単方向 の矢印を付した。この因果関係モデルは，仮説を拡張 して表わしている。仮説を検証するとともに仮説以外 の因果関係を探ることを意図して構築したモデルであ る。
本研究では，このようにして構築したモデルを共分 散構造分析によって分析し，モデルの妥当性を確認し た後, 各潜在変数間の因果関係を調べることによって 仮説の検証を行い，さらに新たな関係も探る。共分散 構造分析では統計パッヶージSASの中のプロシ ジャー「CALIS」を用いた。

\section{結果}

\section{1. 進路意識の構造}

FIG. 1 のパス・ダイアグラムの中に共分散構造分析 によって推定された因果関係を示している。モデルの 全体的評価を行うための指標として， $\chi^{2}$ 検定，残差平 方平均平方根 (RMR), 適合度指標 (GFI), 修正適合度 指標(AGFI)などがある。ここでは，標本数が大きいこ とを考慮して，RMR，GFI，AGFIの值を調べてみ た。結果は, RMR $=0.03, \mathrm{GFI}=0.93, \mathrm{AGFI}=0.91 て ゙$ あった。いずれの指標もモデルとデータの間の適合度 が高いことを示しており，モデルが分散共分散行列を よく説明していることが分かる。

次に，モデルの部分的評価を加えるため，構成概念 から観測変数への影響指標の値を調べてみたが，全て の観測変数で 0.40 以上の値を示し，いずれも統計的に 有意となり，構成概念と観測変数との関係は適切に対 応しているといえる。

構成概念間の因果係数によって仮説の検証を行う。 まず，外生的潜在変数である「適性重視の進路展望 (FX1)」と「学力重視の進路展望 (FX2)」間で 0.19 とや や弱いが相関が認められた。つまり，適性重視の進路 展望をもつ生徒は学力重視の進路展望も併せて持ち合 わせる傾向にあることが確認された。

次に,「適性重視の進路展望 (FX1)」からの因果関係 について考えてみる。各内生的潜在変数への因果係数 は，「学力不足による悩み(FH5)」を除いて統計的に高 度に有意となった。図では，高度に有意となったパス は実線で，有意とはならなかったパスは点線で示して いる。因果係数の絶対值が 0.1 以上のものを取り上げる と,「適性理解のための援助(FH1)」への值が 0.16 , 「適 性重視の進路指導 (FH2)」が0.66,「進路不明による兴 み (FH4)」が-0.14, 「実現可能性と努力 (FH6)」が 0.16 であった。この結果は，概ね次のように解釈すること ができよう。適性を重視した進路展望を抱いている生 徒は, 自己の適性理解のための援助を期待し，また学 力ょりはむしろ自己の興味・関心などに合った進路探 索を行うことができるよう進路指導を担当する高校の 教師に対して指導を求め, 進路不明による悩みも少な 
く進路の実現可能性を高めるための努力もしている。 この因果関係は, 仮説の前半部分を述べていることに 他ならない。

次のもう一方のパスである「学力重視の進路展望 (FX2)」からの因果関係について考えてみる。「学力重 視の進路展望 (FX2)」からのパスは全てで有意となっ た。そのうち因果関係が強いものは「適性理解のため の援助 $(\mathrm{FH} 1)\rfloor て ゙ 0.28$, 「学力重視の進路指導 (FH3)」 で0.64, 「進路不明による悩み(FH4)」で0.18, 「学力不 足による悩み(FH5)」で0.15であった。つまり, 学力重 視の進路展望をもった生徒は, 自己の適性理解のため の援助を期待するが, 進路指導では学力中心の指導を 望む。ただし, 進路不明あるいは学力不足による悩み を抱いており, また進路の実現可能性に向かっての努 力もしていない。この解釈は, 仮説の後半部の一部を 説明している。

以上, 2 つの外生的潜在変数からの流れに沿って内 生的潜在変数との間の因果関係を考えたが, 次に内生 的潜在変数間での因果関係を調べてみる。特徵的な因 果関係を取り上げると,「学力重視の進路指導(FH3)」 $\rightarrow\lceil$ 学力不足による悩み (FH5)」(因果係数-0.12), 「学力 重視の進路指導 (FH3)」 $\rightarrow$ 「実現可能性と努力 (FH6)」 (同 0.21), 「進路不明による悩み (FH4)」 $\rightarrow$ 「実現可能性 と努力 (FH6)」(同-0.33)，「学力不足による悩み(FH5)」 $\rightarrow\lceil$ 実現可能性と努力 (FH6)」(同一0.72) などがある。 これらの構成概念間の因果関係は,「適性重視の進路展 望 (FX1)」や「学力重視の進路展望 (FX2)」の影響を考 慮した上での関係を示しているので，その結果から， 1 つは, 学力重視の進路展望をもつ生徒は学力不足に よる悩みも少なく，また進路の実現可能性へ向かって の努力をしているという関係と，もう 1 つは，進路不 明や学力不足による悩みを抱えている生徒は, 進路の 実現可能性に向かって努力をしていないという関係を 指摘することができる。これらの指摘は, 仮説の後半 部の一部を説明している。

このような解釈の妥当性を確認するため，構成概念 間の相関行列を求めた。TABLE 2 はその結果を示した ものである。上の解釈に対応する構成概念間の相関は 大部分で高い値を示し，それ以外では低い値となって いることから，ほぼ解釈は妥当であることが認められ た。従って, 各段で述べた解釈を統合することにより, 因果関係モデルを構築する際に設けた仮説が妥当であ ることが確認された。

\section{2. 性差および学年差からみた進路意識の差異}

FIG. 1に示した因果関係モデルを，男子および女子
TABLE 2 構成概念間相関行列

\begin{tabular}{lrrrrrrrrr}
\hline 適性重視の進路展望 & 1.00 & & & & & & & \\
学力重視の進路展望 & .19 & 1.00 & & & & & & \\
適性理解のための援助 & .21 & .31 & 1.00 & & & & & \\
適性重視の進路指導 & .68 & .08 & .27 & 1.00 & & & & \\
学力重視の進路指導 & .09 & .68 & .37 & .05 & 1.00 & & & \\
進路不明による悩み & -.04 & .16 & .05 & .02 & .12 & 1.00 & & \\
学力不足による悩み & .01 & .06 & -.00 & -.00 & -.02 & .01 & 1.00 & \\
実現可能性と努力 & .19 & -.01 & .08 & .14 & .14 & -.33 & -.73 & 1.00 \\
\hline
\end{tabular}

にそれぞれ適用し，共分散構造分析によって調べてみ た。男子の場合, $\mathrm{RMR}=0.04, \mathrm{GFI}=0.93, \mathrm{AGFI}=$ 0.90 , 女子の場合, $\mathrm{RMR}=0.03, \mathrm{GFI}=0.94, \mathrm{AGFI}=$ 0.92 を得た。いずれのモデルもデータとの適合度が高 いことが確認された。パス・ダイアグラムによって, 進路意識の構造の違いを調べたところ,「適性重視の進 路展望 (FX1)」と「学力重視の進路展望 (FX2)」の間の 相関係数に差異が見られた。男子は 0.21 , 女子は 0.13 であった。また, 因果係数の比較を通して, 女子は男 子に比べ「実現可能性と努力 (FH6)」に対する「適性重 視の進路展望 (FX1)」の規定力が弱まり（因果係数く男子 $: 0.20$ 女子 : 0.09〉), また「学力重視の進路指導 (FH3)」 に対する「学力重視の進路展望 (FX2)」の規定力も弱ま る特徴が見出せた（男子: 0.68 女子: 0.56)。なお，その 他の因果関係は，男女による差異はほとんど見られな かった。

次に，各構成概念について男女差を調べてみること にした。因果関係モデルによる共分散構造分析は，各 構成概念の水準を外した変動情報に基づく構成概念間 の関係を記述したものである。このため，同一モデル をそれぞれ異なる集団に対して適用し共分散構造分析 を行った場合, 因果係数による関係の比較を行うと共 に各構成概念の水準 (平均) についても比較検討してお くことが有用である。ここで用いた構成概念は, 因子 を代表する典型的な項目の集合であることを考慮し， それらの項目の合計点（概念得点）によって構成概念を 表現することにして，男子と女子の平均値の比較を 行った。TABLE 3 は, 概念得点について男子と女子の 平均値を比較した結果を示したものである。「学力不安 による悩み(FH5)」と「実現可能性と努力 (FH6)」を除 いた全ての構成概念について高度に有意となった。分 析の対象となった標本数が多数であることを考慮して も，女子は男子に比べ進路意識が高く，進路に関わる 援助を求め, また進路不明による悩みも高い傾向にあ ることが示唆された。ただし，因果関係で得られた結 
果を考慮すると，女子は男子に比べ適性観と学力観の 関連性が薄く，また，適性を重視した進路展望をもつ たとしても，それが必ずしも進路実現可能性を高める ための努力とは結びつかず，学力を重視したとしても， 学力重視の進路指導を求める姿勢は男子に比べ弱い傾 向にあることが見出された。

TABLE 3 概念得点の平均値の比較（性別）

\begin{tabular}{|c|c|c|c|}
\hline 構成概念 & 男 & 女 & $\mathrm{t}$ 值 \\
\hline 適性重視の進路展望 & $13.82(2.06)$ & $14.56(1.64)$ & $-24.29^{* *}$ \\
\hline 学力重視の進路展望 & $6.74(1.27)$ & $6.87(1.11)$ & $-6.62^{* *}$ \\
\hline 適性理解のための援助 & $10.51(2.41)$ & $11.37(2.05)$ & $-23.10^{* *}$ \\
\hline 適性重視の進路指導 & $12.34(2.38)$ & $12.81(2.04)$ & $-12.81^{* *}$ \\
\hline 学力重視の進路指導 & $9.07(1.71)$ & $9.34(1.41)$ & $-10.14^{* *}$ \\
\hline 進路不明による悩み & $7.71(2.52)$ & $8.09(2.43)$ & $-9.18^{* *}$ \\
\hline 学力不足による兴み & $9.23(1.85)$ & $9.27(1.70)$ & -1.35 \\
\hline 実現可能性と努力 & $5.59(1.48)$ & $5.52(1.34)$ & $2.96^{*}$ \\
\hline
\end{tabular}

$(* \mathrm{p}<.01, \quad * * \mathrm{p}<.001) （ ）$ 内は標準偏差

次に学年差による進路意識の違いについて調べてみ た。男女差の場合と同様な因果関係モデルを分析の対 象となった 1 年生と 2 年生のそれぞれに適用した。共 分散構造分析の結果, 適合度指標として 1 年の場合, $\mathrm{RMR}=0.03, \mathrm{GFI}=0.93 \mathrm{AGFI}=0.91,2$ 年の場合, $\mathrm{RMR}=0.04, \mathrm{GFI}=0.93, \mathrm{AGFI}=0.901$ を得た。いず れもモデルとデータの適合度が高いことが確認された。

1 年と 2 年の因果関係モデルにおいて対応するパスの 因果係数を比較したところ，「学力重視の進路指導

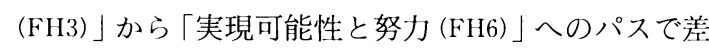

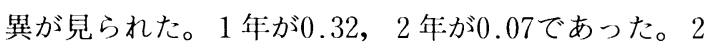
年の場合, 学力重視の進路指導と進路実現可能性を高 める努力とは独立性の高い関係にあることが示唆され た。その他の因果関係は，学年による差異はほとんど 見られなかった。

また，構成概念の水準の差異を調べるため，概念得 点の平均值の差の検定を行ったところ,「実現可能性と 努力 (FH6)」においてのみ高度な有意差が認められ $(\mathrm{t}=-13.72, \mathrm{p}<.001), 2$ 年の方が 1 年に比べ高い值と なった。2 年になると進路実現可能性を高めるための 努力をしていることが分かる。

\section{3. 高校の進学率の違いからみた進路意識の差異}

高校の組織的な影響をみる指標として進学率の違い を取り上げて, それが生徒の進路意識の構造にどのよ うな影響を与えているかを調べた。

ここでは，84校の高校について，進学率が40\%以下
を「進学率低」，40～80\%を「進学率中」，80\%以上を 「進学率高」として 3 群に分類した。各群の高校数は, それぞれ23校, 25校, 36校である。分析では「進学率 低」と「進学率高」の学校の生徒を対象にして, 同一 の 2 つの因果関係モデルを構築し共分散構造分析を 行った。分析の結果, 適合度指標として「進学率低」 「進学率高」共, $\mathrm{RMR}=0.04, \mathrm{GFI}=0.92, \mathrm{AGFI}=0.90$ の值を得た。いずれもモデルとデータの適合度が高い ことが確認された。因果係数の差異がみられた因果関 係としては,「学力重視の進路展望 (FX2)」 $\rightarrow$ 学力不 足による悩み (FH5)」（進学率低：0.20, 進学率高 : 0.07), 「学力重視の進路展望 (FX2)」 $\rightarrow$ 「実現可能性と努力 (FH6)」（進学率低: 0.02, 進学薪高 : - 0.15)があった。その 他のパスでは因果関係に大きな差異が認められなかっ た。

次に, 進学率の違いによって各構成概念の水準に差 異が認められるか否かを確認するため, 進学率に関す る 1 要因分散分析を行い, 併せてダンカンの検定によ るグルーピングも行った。平均値の比較を行った結果 をTABLE 4 に示す。表に示すように，「学力重視の進 路展望 (FX2)」「学力重視の進路指導(FH3)」を除いた 6 つの構成概念で高度に有意となった。グルーピング の結果,「進学率高」とそれ以外の群にグループ化でき た構成概念として「適性重視の進路展望 (FX1)」「適性 重視の進路指導 (FH2)」「進路不明による悩み (FH4)」 「実現可能性と努力 $(\mathrm{FH}$ 6)」があった。「進路不明による 悩み（FH4）」を除いた構成概念については，いずれも 「進学率高」のグループの方が高い平均値を示してい た。「進路不明による悩み(FH4)」は逆に「進学率高」 の方が低い值であった。また，「進学率低」とそれ以外 にグループ化できた構成概念として「学力不足による 悩み(FH5)」があった。「進学率低」のグループが他の グループに比べ高い平均値を示していた。

TABLE 4 概念得点の平均値の比較（進学率）

\begin{tabular}{l|rrrr}
\hline \multicolumn{1}{c|}{ 構成概念 } & \multicolumn{1}{c}{ 進学率低 } & \multicolumn{1}{c}{ 進学率中 } & 進学率高 & F 值 \\
\hline 適性重視の)進路展望 & $14.07(1.95)$ & $14.07(1.97)$ & $14.21(1.89)$ & $9.18^{* *}$ \\
学力重視の進路展望 & $6.82(1.20)$ & $6.79(1.22)$ & $6.79(1.20)$ & 0.77 \\
適性理解のための援助 & $11.00(2.24)$ & $10.91(2.33)$ & $10.75(2.32)$ & $14.08 * *$ \\
適性重視の進路指導 & $12.46(2.22)$ & $12.45(2.30)$ & $12.64(2.24)$ & $11.23 * *$ \\
学力重視の進路指導 & $9.23(1.58)$ & $9.19(1.60)$ & $9.16(1.61)$ & 1.85 \\
進路不明による悩み & $7.95(2.44)$ & $7.92(2.47)$ & $7.77(2.54)$ & $7.86 * *$ \\
学力不足による悩み & $9.32(1.71)$ & $9.22(1.77)$ & $9.21(1.85)$ & $5.67 * *$ \\
実現可能性と努力 & $5.49(1.38)$ & $5.44(1.42)$ & $5.68(1.44)$ & $43.52^{* *}$ \\
\hline
\end{tabular}

(** p p.001)（）内は標準偏差 


\section{考察}

本研究の目的の 1 つは, 進路意識について, 仮説に 沿った因果関係モデルを構成し, 共分散構造分析に よって仮説の妥当性を確認することであった。分析の 結果, データとモデルの適合度は高く, 構成概念間の 関係を検討することによって仮説が支持された。多く の学校で学力中心の進路指導が行われている現状では, 生徒も学力偏重の進路意識にならざるをえないものと 予想されたが,「適性重視の進路展望」と「学力重視の 進路展望」との間に有意な相関が見られたことから， 生徒の進路意識の中には, 学力と適性は独立して存在 するものではなく, 相互に関わりをもった形で同居し ていることが分かった。その中で適性重視の進路展望 を抱く生徒は援助, 不安, 努力に対して整合性の高い 方向が示されたが, 学力重視の進路展望を抱いた生徒 は学力重視の進路指導を希望するか否かによってまっ たく異なる方向を示した。学力重視の進路指導を望む 生徒は, 学力不足による悩みも少なく, また進路へ向 かっての努力をしている。しかし，単に学力を重視し た展望をもつだけでは, 悩みも多く進路へ向かっての 努力を行っていない。このことは, 進路指導において, 学力を重視することが学力面での将来の成功の鍵と なっていることを示唆しており, 学力中心の進路指導 に対する生徒の意識の一面が表われたものと考えるこ とができる。

ところで, パス・ダイアグラムから, 不安要因と強 く関係している構成概念として「実現可能性と努力」 がある。そこで興味を引くのは，悩みを感じる生徒ほ ど将来の進路の実現可能性は低いし，努力もしていな いという負の相関をもっていた点である。本来，進路 不明や学力不足による悩みを感じる場合，その悩みを できるだけ減少するための自己努力がなされるべきで あるが, 結果はその逆であった。ところで, 進路指導 および進路情報の提供によって，生徒に進路展望を持 たせるためには，それを利用する生徒側にある程度の レディネス (準備性) が備わっていなければならない。 従って, 進路について检みを抱いている生徒に対して は，生徒のさまざまな進路に対する学習意欲を向上さ せ，進路に対する成熟した意識を持たせることによっ て, 望む進路の実現に向かって生徒が努力することに なる。

研究の第 2 の目的は, この因果関係モデルを利用し て, 性, 学年, 進学率などの要因分析を試みることで あった。共分散構造分析の文脈では, 名義尺度である
性や学年といった情報を直接因果関係の中に取り組む ことができない。ここでは, 各カテゴリ毎に同一の因 果関係モデルを構築し, 因果係数の比較を通して評価 する方法をとった。比較の際, 統計的有意性を検定す ることができないという問題点は残るが，名義尺度を 用いた要因分析を行う際の 1 つの考え方として存在す ると思われる。分析の結果として得られた知見の 1 つ は, 設定した因果関係モデルによる進路意識の構造に ついて, 性, 学年, 進学率による大きな差異が見られ なかった点である。高校 1 年あるいは 2 年という時期 は, 職業的展望に抢ける探索期にあたり（中西・広井, 1981), 将来の進路・職業について思考, 模索しながら学 習していく時期である。その時期の青年達の進路意識 の構造が性や学年あるいは進学率の高低によらずほぼ 同じ因果関係を保持している点はよく認識しておく必 要があろう。

ただし，因果関係の一部で差異が見られたので，そ の点を考慮しながら, 性差, 学年差あるいは進学率の 差異による特徵を若干考察してみる。性差に関しては, 因果関係を構成する 8 つの構成概念のうち 6 つの構成 概念で平均値の差が高度に有意となった。いずれも女 子の方が男子より高い値を示していた。女子は男子に 比べ成熟が早いと言われているが (中西・広井, 1981)，こ の平均值の差異は男女の成熟過程の違いをよく表わし たものと考えられる。ただし，女子は，進路に対する 適性観と学力観を遊離した形で捉えており，また適性 観や学力観をもっていたとしても，それが進路上での 援助や努力へとつながらない傾向がある。

学年差に関しては，「実現可能性と努力」の平均値だ けが高度に有意となり，他の構成概念では有意差は認 められなかった。基本的な因果関係は保持しながら， 学年の進行に伴い, 実現可能性へ向かっての努力を高 めていく方向が確認された。ただし、その努力は主と して不安要因から生じたものであって，進路指導によ る他者からの援助は 2 年になるとあまり影響を与えて いない。

先行研究では，学校間格差が生徒の意識や行動を強 く規定している（竹内, 1981 ; 耳塚, 1982）と述べている。 そこで, 本分析では, 進路意識の構造でも異なった様 相を見出すことができるであろうと考え，進学率の異 なる学校の生徒を 3 群にカテゴリ化 (進学率低, 進学率中, 進学率高) し，そのうち「進学率低」と「進学率高」の 2 群について同一の因果関係モデルを用いて進路意識 の構造の差異を調べてみた。分析の結果, 進学率の高 い学校の生徒に対しては, 学力を重視した進路展望を 
もつことが必ずしも不安の助長や将来の進路実現へ向 かっての努力につながるものではなく，むしろ努力に 対しては逆結果をもたらしている傾向が見られた。進 学率の高い学校の生徒は, 学力重視の進路展望は不安 や努力を規定しては抢らず，むしろ「適性重視の進路 展望」「適性重視の進路指導」「実現可能性と努力」な どの適性観に関する構成概念でいずれも高い平均値を 示していることを考えると，適性を考慮した進路探索 の姿勢は, 進学率の高い学校の生徒ほど着実であり, 進路意識に対する成熟度の高さが何える。

この調査で対象とした生徒は, 進路選択として大学 への進学を目指す者が多いと想定される。そのような 状況の中で生徒は, 将来に関する進路展望を興味・関 心・意欲などの適性を中心においた適性観と学力を中 心においた適性観の両面から捉えており，また進路に 関する援助の必要性を感じながら進路に対する不安を 抱えているごとが示された。Gothard と Goodhew （1987）は，個人，教育，職業の 3 側面を配慮した進路 指導が望ましいと述べているが，上で述べた性差によ る進路意識の違いや進学率の違いによる問題などをき め細かに配慮しながら進路指導を推進していくことが 望まれる。

最後に本研究では, 生徒の進路意識を援助, 悩み, 行動という枠組みの中で仮説を設定し，因果関係モデ ルによる分析を試みた。いくつか0因果関係モデルを 構築しながら, 最も妥当であると考えたモデルが本モ デルである。用いられた調査項目が限られていたため, 進路意識の構造の全容が明らかになったわけではない。 しかし, 一部にしても, 進路意識の構造が整理され, 問題点が指摘できたという点でこのような因果関係モ デルの利用は有用であると思われた。

\section{引用文献}

大学入試センター 1991 高等学校の進学指導におけ
る個性尊重に関する調査研究報告書

Gothard, W.P., \& Goodhew, E. 1987 Guidance and the Changing Curriculum. Croom Helm.

浜田哲郎 1991 大学教官から見た専攻学生の適性像 と行動特性 九州大学教養部カウンセリング学科 論集 $5,1-43$.

Joreskog, K.G., \& Sorbom, D. 1984 LISREL VI Usere's Guide : Analysis of linear structural relationships by the models of maximum likelihood. Chicago : National Education Resources.

耳塚寞明 1982 学校組織と生徒文化・進路形成 教 育社会学研究, 37, 34-46.

中西信男・広井甫 1981 進路指導の心理と技術 福 村出版

下山晴彦 1984 ある高校の進路决定過程の縦断的研 究 教育心理学研究, 32, 3, 43-48.

Super, D.E. 1953 A theory of vocational development. American Psychologist, 8, 185-190.

竹内清 1981 高校における学校格差文化 教育社会 学研究, 36, 137--144.

豊田秀樹ほか 1991 高等学校の進路指導の改善に関 する因果モデル構成の試み 教育心理学研究, 39, $316-323$.

豊田秀樹 1992 SASによる共分散構造分析 東京 大学出版会

柳井晴夫ほか 1989 進路指導と大学情報に関する調 查結果の分析 大学入試センター研究紀要 18,1 -72 .

柳井晴夫 1973 適性診断における診断方式の検討 (II) 教育心理学研究, 21, 3,148-159.

(1993. 3 .23受稿，4 .27受理) 